\title{
Energy efficiency in municipal waste treatment
}

\author{
Elena Vialkova ${ }^{1, *}$, Marina Zemlyanova ${ }^{1}$ and Oleg Danilov ${ }^{1}$ \\ ${ }^{1}$ Tyumen Industrial University, Volodarskogo str., 38, Tyumen, 625000, Russia
}

\begin{abstract}
The article presents the efficient method of microwave irradiation (SHF) for the municipal liquid waste such as domestic wastewater and sludge. The technical and economic parameters and experimental data, showing the possibilities of microwave electromagnetic radiation using in the sewage and sediment treatment technologies, are given in this article. The traditional electrothermal treatment and SHF processing of the municipal precipitation, taken from the city wastewater treatment plant, have been compared. At the same time, a high rate of heating of the precipitation samples has been noted during the microwave treatment. The technical and economic comparison of three methods (with the usage of the reagents, convection heating and SHF) showed the advantages of using SHF range electromagnetic radiation. The energy efficiency and the cost-effective use of resources during the SHF using for liquid municipal waste treatment have been confirmed.
\end{abstract}

\section{Introduction}

The environment of the modern world has become increasingly polluted. One of the reasons for the worsening of the world ecology state is the discharge of the untreated sewage into the water sources and the accumulation of massive amounts of precipitation around the cities and settlements. The problem of the effective treatment and economical utilization of the municipal liquid waste is urgent worldwide. The problem of the qualitative sewage treatment and sediments' processing with the further utilization is also important for cities, towns and villages in Russia. The indicators of the domestic wastewater quality such as the suspended matter, biological oxygen demand (BOD), chemical oxygen demand (COD) and nitrogen of ammonium salts depend on the amount of the wastewater undergoing the treatment (table 1) [1-3].

At the Wastewater Treatment Plants (WWTP), especially in the northern cold conditions, it is necessary to use a big amount of traditional equipment units, huge quantity of energy and resources to ensure the normative water quality.

\footnotetext{
*Corresponding author: vyalkova-e@yandex.ru
} 
Table 1. Average data on wastewater quality (for settlements of Tyumen region).

\begin{tabular}{|c|c|c|c|c|c|}
\hline Kind of Settlement & $\begin{array}{c}\text { WWTP } \\
\text { productivity, } \\
\mathbf{m}^{\mathbf{3} / \mathbf{d a y}}\end{array}$ & $\begin{array}{c}\text { Suspended } \\
\text { matters, } \\
\mathbf{m g} / \mathbf{d m}^{\mathbf{3}}\end{array}$ & $\begin{array}{c}\mathbf{B O D}, \\
\mathbf{m g} / \mathbf{d m}^{\mathbf{3}}\end{array}$ & $\begin{array}{c}\mathbf{C O D ,} \\
\mathbf{m g} / \mathbf{d m}^{\mathbf{3}}\end{array}$ & $\begin{array}{c}\mathbf{N}-\mathbf{N H}_{\mathbf{4}}, \\
\mathbf{m g} / \mathbf{d m}^{\mathbf{3}}\end{array}$ \\
\hline Construction camp & $5-200$ & $400-3000$ & $400-900$ & $700-5500$ & $70-150$ \\
\hline Village & 400 & 240 & 390 & 500 & 72 \\
\hline Settlement & 1000 & 150 & 110 & 200 & 35 \\
\hline Town & 40000 & 195 & 250 & 400 & 26 \\
\hline City & 210000 & 305 & 180 & 350 & 34 \\
\hline
\end{tabular}

The operating cost of such facilities is unreasonably high due to the electricity price and a large volume of consumables. Table 2 presents the calculated average values of the precipitation volumes that are formed during the sewage settling in the precipitation tanks at the treatment plants of different settlements.

Table 2. The amounts of forming wastewater sludge.

\begin{tabular}{|c|c|c|c|}
\hline Residents & $\begin{array}{c}\text { The productivity of } \\
\text { WWTP, } \mathrm{m}^{3} / \mathrm{day}\end{array}$ & $\begin{array}{c}\text { The amount of } \\
\text { forming sludge, } \\
\mathrm{m}^{3} / \mathrm{day}\end{array}$ & $\begin{array}{c}\text { The amount of } \\
\text { forming sludge, } \\
\text { thousand } \\
\text { tons/year }\end{array}$ \\
\hline $\begin{array}{c}\text { Construction camps, 0.1- } \\
0.5 \text { thousands }\end{array}$ & $10-250$ & $0.1-1$ & $0.04-0.4$ \\
\hline $\begin{array}{c}\text { Settlements, } \\
1-5 \text { thousands }\end{array}$ & $400-1000$ & $2-10$ & $0.7-3.7$ \\
\hline $\begin{array}{c}\text { Towns, } \\
40-100 \text { thousands }\end{array}$ & $7000-40000$ & $40-250$ & $15-90$ \\
\hline $\begin{array}{c}\text { Cities, } \\
300-700 \text { thousands }\end{array}$ & $100000-220000$ & $600-1800$ & $200-600$ \\
\hline
\end{tabular}

Due to the population growth, the sewage amount increases and thus, the sediment amount which should be treated and utilized rises. It should be noted that treatment price of one cubic meter of wastewater at the stations with low productivity is higher (in 4-10 times) than for the stations with medium or large productivity.

In recent years, the microwave irradiation (SHF) has been widely used as an effective thermal method for the wastewater and sludge treating, mainly due to its rapid and selective heating, energy efficiency, the ability to increase productivity and product quality, and to reduce the formation of hazardous products.

The original method of microwave electromagnetic radiation (SHF) using for the municipal liquid waste is shown in this article. Some problems of the high-quality wastewater treatment and sludge utilization can be solved with this method.

\section{Review}

The problem of the processing and utilization of sewage and sludge is quite serious for the city municipal services. Unfortunately, only $10-15 \%$ of all sediments is processed by modern technologies [1]. One of the new ways of treating municipal liquid waste is the electromagnetic microwave irradiation $[2,3]$.

The electromagnetic radiation influences mostly the heterogeneous water systems or processes, connected with the phase transitions (dilution, crystallization and others). These achieved effects are quite substantial and save much time, but in some cases they are irreversible. One of the new directions of the microwave energy usage is a production waste 
and domestic waste treatment with the aim of their further utilization. Interesting results have been obtained in the field of investigation of the liquid and solid municipal waste treatment processes using the electromagnetic microwave fields [4-20].

The high-frequency irradiation application effectiveness for the increase of the hydrocarbon-oxidizing bacteria activity has been shown. [6]. The electromagnetic activation of bio system increases the aeration facilities' oxidative capacity for more than $40 \%$, and the amount of silt index declines to $45 \%$. In addition, the way of wastewater disinfection, which is based on the usage of perpendicular stream of the constant magnetic field with a definite intensity, has been worked out. [7]. The technology and the industrial technological plant for the oil slime treatment with the use of SHF energy has been developed [8].

The industrial wastewater disinfection method with the magnetic intensity $70-80 \mathrm{kA} / \mathrm{m}$ and frequency $2-10 \mathrm{imp} / \mathrm{sec}$ in the impact electromagnetic facility is known [9]. The microwave irradiation is one of the new and possible methods which is used for the industrial wastewater precipitation pre-treatment. Not only the increase in biogas production has been researched, but also the hydrolysis of proteins and carbohydrates has been carried out successfully by the SHF preliminary treatment, even with a low energy consumption of irradiation [10]. Besides, the good research results of the convection heating and heating of the sewage sludge from food production by means of ultrahigh-frequency waves (SHF) have been also obtained [11].

The analysis of the SHF-waves influence on some physical and chemical properties of the active silt of food industry treatment plants has been done. It is proved that the active silt SHF treatment leads to the essential increase of its precipitation speed and compaction degree [12]. Therefore, it is proved that the microwave treatment of sewage sediments allows to remove the admixture of the heavy metals from the sediments with the power inputs of no more than $0.05 \mathrm{~kW}$-hour $/ \mathrm{kg}$ [13]. Besides, the complex method of the sewage sediment reagent-less treatment includes the disinfection of active silt briquettes in microwave ovens [14].

The microwave reactor is able to treat 100 thousand tons of solid household waste a year. There is a special camera, where the microwaves and the fuel gas have heated the wastes, in this reactor [15]. Under the influence of these two temperature impacts, the substance has been decomposed without oxygen. The substance is decomposed into three components: the carbonic residuum, gas fraction and different components, which are compensated then and turn into the furnace oil or motor product. [16].

The microwaves with the frequency of $2.45 \mathrm{~Hz}$ and the processing power of $1200 \mathrm{~W}$ have been applied to the dehydrated municipal wastes. During the thermal decomposition of the organic matter in the semi-industrial reactors, the methane output was recorded [17].

In 2016, a new method of the sewage sludge mix microwave treatment has been patented in Russia, as a way of the suspended matters' sedimentation intensification, the moisture reduction, the sludge volume reduction, and other sediment properties' improving [18].

Internationally, there is a well-known microwave reactor ATON 200 for the asbestoscement waste products' treatment, introduced and patented by the Poland firm. The technology can be applied to any type of the solid and soft asbestos waste, for example the gyps-asbestos, the conduits, the cords, the pads and others. Such reactors work in France and in the USA nowadays. The company has an experience of the asbestos and sulfuric tar, polluted with hydrocarbons, utilization. During the treatment process, there is a mass reduction (on 75-99\%) of the in-process material. [2]

According to many authors, who have studied the SHF-method, the biological effect of electromagnetic fields is characterized by the thermal action and non-thermal effect. The thermal action refers to an integral increase in the temperature of the body or of its individual parts under the general or local irradiation. The non-thermal effect is associated with the transition of the electromagnetic energy in the object to a non-thermal energy form, in 
particular, the molecular resonance depletion energy, photochemical reactions, and other kinds [11, 18-20]. This combined effect of the microwave irradiation offers a number of advantages over the conventional heating, which are subject to further study and can be used in water treatment and treatment of liquid municipal waste technologies.

\section{Problem}

Tyumen region is one of the largest in Russia, it covers an area of 1.5 million square kilometers, and the population is more than 3.5 million people. This is a land of oil and gas production. There are 30 cities with the population of more than 20 thousand inhabitants. There are more than 100 towns and villages. The problem of qualitative sewage treatment and sediments processing with the further utilization is urgent for all towns and villages. The dynamics of the water pollution concentration changing is as follows: the greater the productivity of the wastewater treatment plant, the lower the concentration of the pollutants (Fig.1). The water and sludge treatment's cost price has reduced definitely with the increase of WWTP productivity (Fig. 2).

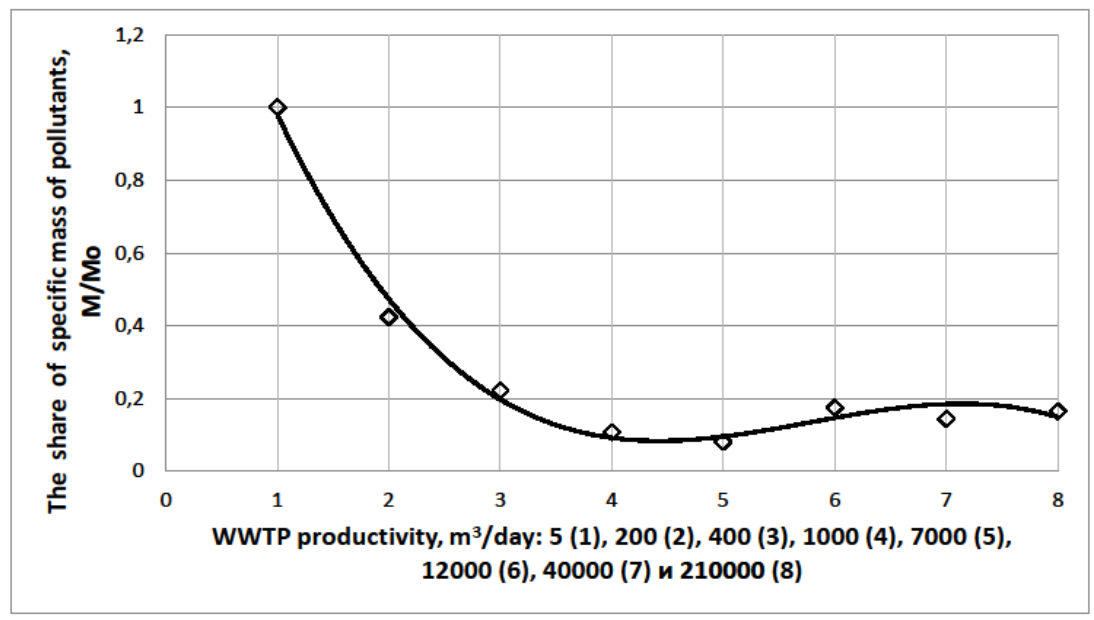

Fig. 1. The change in the specific reduced mass of pollution. Legend: Mo - maximal pollution mass, $\mathrm{M}$ - pollution mass at different productivity. 


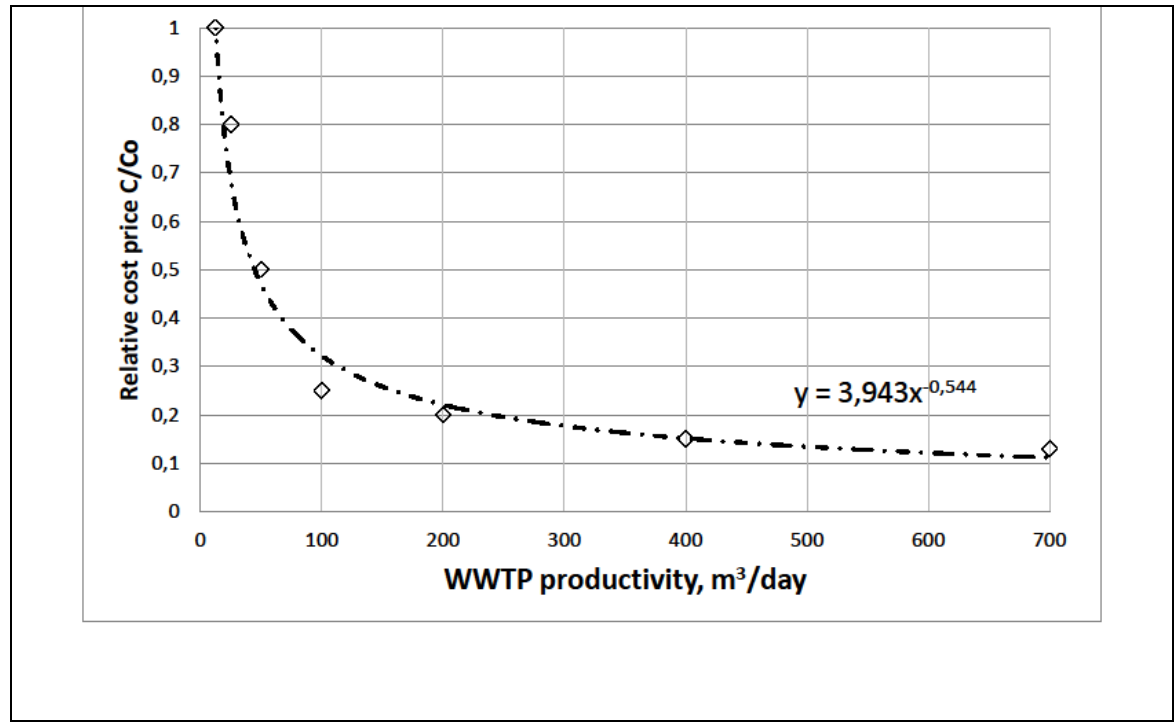

Fig. 2. Dynamics of cost price WWTP operation. Legend: Co - maximal cost price of wastewater treatment and sludge utilization, $\mathrm{C}$ - cost price at different WWTP productivity.

The issue of accumulation and processing of such liquid municipal waste is quite urgent too. There are serious problems with the wastewater sludge treatment and their utilization. The spatial structure of the sludge mix is a colloidal system, which includes the fine-dispersed solid particles. The total negative charge on the surface of the colloidal particles causes the mutual repulsion, and, as a result, the sediments cannot be precipitated and filtered. $[2,3]$

The resulting sludge cannot be utilized as agricultural fertilizers or raw materials for construction or for another purpose due to unsatisfactory quality. The main reasons of this are the unideal technologies, the high cost of reagents, high-energy costs, and poor operation of the treatment plants. The existing popular methods, used nowadays in northern regions, have a range of disadvantages and are not always effective. As a result, the areas occupied by the silt fields and the sludge accumulators, increase every year. Only 20-30\% of all sludge is disposed of properly [3].

\section{Description of studies}

At the Chair of Water Supply and Sewerage Systems (Industrial University of Tyumen), the research of the SHF-radiation influence on the municipal sewage and sludge quality has been done. The researchers have been carrying out the experiments, concerning the SHF-radiation treatment of wastewater and the mixture of damp sediment and active silt (in ratio 1:2), for several years. The experimental compact SHF-plant "Flow EM-1" for the in vitro study has been made [17].

The microwave impact to the municipal sewage quality has been examined. The wastewater samples taken from WWTP of northern settlements of Tyumen region, have been processed. The processing duration has been five minutes on the first and the second stages. It should be noted that the water samples' temperature has reached $80-100^{\circ} \mathrm{C}$ during the experimental time. The standard quality water indices, such as suspended matters, BOD, COD, ammonium-ion sulfates, chlorides and others have been measured by standard methodologies. 
The experiments showed that the quality of sewage under the influence SHF electromagnetic irradiation has changed for the better. The change of the water indexes after the microwave treatment is shown in Table 3.

It is evident that due to the microwave treatment, there are the dissociated molecules and free radicals, and also the electrical charges in the sewage sediments. There is an equilibrium shift of the colloidal systems, and, as a consequence, the water repellent properties of the sediment improve. During the SHF-radiation, the volumetric rise in sludge samples' temperature is obvious. The moisture evaporation increases, and this fact provides the sediment volume decline. Due to high oxygen activity, the oxidizing processes, including the organic substances' decomposition, become more intense. Besides, there is a cellulose destruction as useful side effect. The microorganism cell ferments' activity reduction, disinfection and destruction of the helminthes eggs, pathogenic bacteria, simplify the further utilization of the sediments. The main changes of sludge properties after SHF irradiation is shown in Table 4.

The comparison of microwave and convectional heating has been done. A distinctive feature of microwave heating is that its effect is of a volumetric nature and does not require, as in the case of traditional heating, the thermal diffusion from the surface into the interior of the material, which explains its thermo-reaction high rates. There is also a rapid thermal effect, which exerts super high frequency irradiation on the liquid wastewater precipitation: within 1-2 minutes, the sludge samples of 100-200 ml volume have begun to boil (the result is on the Fig.3).

Under the influence of high temperature because of intensive evaporation of moisture, it has been possible to reduce the humidity and the volume of the precipitation in a short period. At the same time, the power consumption is lower by approximately 2.5-3 times than the energy consumption for traditional electrothermal heating.

Table 3. The change of water indexes after microwave treatment.

\begin{tabular}{|c|c|c|c|}
\hline Water Indexes & $\begin{array}{c}\text { Inlet } \\
\text { concentration } \\
\text { before SHF, } \\
\mathrm{mg} / \mathrm{dm}^{3}\end{array}$ & $\begin{array}{c}\text { Outlet } \\
\text { concentration } \\
\text { after SHF, } \\
\mathrm{mg} / \mathrm{dm}^{3}\end{array}$ & Description of Results \\
\hline $\begin{array}{l}\text { Suspended } \\
\text { matters }\end{array}$ & 940 & 850 & $\begin{array}{l}\text { The concentration decreases from } 940 \\
\text { to } 450 \mathrm{mg} / \mathrm{dm}^{3} \text { (after first stage), and } \\
\text { then increases to } 850 \mathrm{mg} / \mathrm{dm}^{3} \text { (after } \\
\text { second stage). Efficiency is } 9.5 \%\end{array}$ \\
\hline COD & 1240 & 490 & Efficiency is $60.5 \%$ \\
\hline BOD & 430 & 250 & $\begin{array}{c}\text { The concentration decreases from } 430 \\
\text { to } 250 \mathrm{mg} / \mathrm{dm}^{3} \text { (after first stage), and } \\
\text { then increases to } 280 \mathrm{mg} / \mathrm{dm}^{3} \text { (after } \\
\text { second stage). Efficiency is } 35 \%\end{array}$ \\
\hline $\begin{array}{l}\text { Ammonium- } \\
\text { ion }\end{array}$ & 200 & 150 & Efficiency is $25 \%$ \\
\hline Nitrate-ion & 0 & 3.8 & $\begin{array}{l}\text { The concentration increases by reason } \\
\text { of the destruction of organic matters } \\
\text { and transformation ammonium nitrogen } \\
\text { into nitrate-ion }\end{array}$ \\
\hline Phosphate-ion & 29 & 19 & Efficiency is $34.5 \%$ \\
\hline Sulfates & 14 & 2 & Efficiency is $85.7 \%$ \\
\hline Chlorides & 4.8 & 2.8 & Efficiency is $41.7 \%$ \\
\hline $\mathrm{pH}$ & 6.04 & 7.33 & The environment became more neutral \\
\hline
\end{tabular}


Table 4. The change of sludge properties after SHF irradiation.

\begin{tabular}{|c|c|c|c|}
\hline $\begin{array}{c}\text { Sludge } \\
\text { Indexes }\end{array}$ & Before SHF & After SHF & Description of Results \\
\hline Humidity & $97-98.5 \%$ & $94-96.5 \%$ & Efficiency is 2-3\% \\
\hline $\begin{array}{c}\text { Specific } \\
\text { resistance of } \\
\text { filtration }\end{array}$ & $\begin{array}{c}36-40 \\
10^{10} \mathrm{~g} / \mathrm{cm}^{3}\end{array}$ & $\begin{array}{c}6-7 \\
10^{10} \mathrm{~g} / \mathrm{cm}^{3}\end{array}$ & Efficiency is $82.5 \%$ \\
\hline Ash content & 36.86 & 39.1 & Efficiency is $6.1 \%$ \\
\hline $\begin{array}{c}\text { Time of } \\
\text { compaction }\end{array}$ & 3.5 hour & 1.5 hour & Efficiency is $57 \%$ \\
\hline $\begin{array}{c}\text { Putrescibility } \\
\text { Begins after } \\
2-4 \text { hour }\end{array}$ & $\begin{array}{c}\text { after 2 days no } \\
\text { begins }\end{array}$ & Good result \\
\hline Disinfection & $0 \%$ & $99 \%$ & Very good result \\
\hline
\end{tabular}

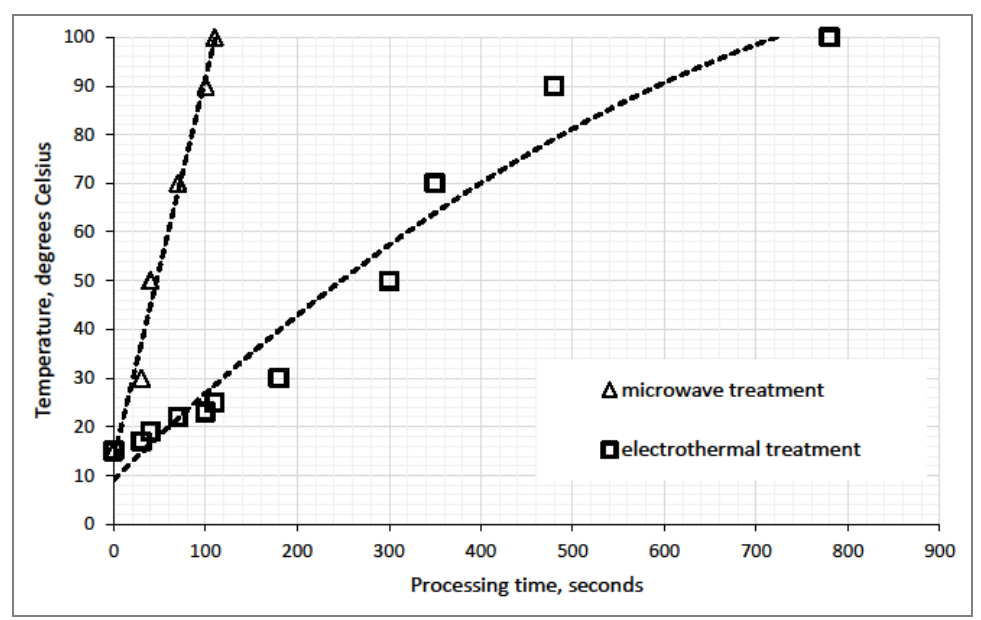

Fig. 3. The comparison of two methods of heating sludge.

Figure 3 shows the comparative heating curves for the mixture of precipitation by two methods, with the heating rate of precipitation to a given temperature by means of microwaves 4-6 times higher. In addition, in the process of the microwave irradiation, the improvement in the sewage sludge deposition and compaction by $13-15 \%$, in comparison with traditional convective heating up to the same temperature, has been obtained.

Thus, the possibility of the reagent-less method of wastewater treatment and the urban municipal waste neutralization with the microwave electromagnetic treatment has been experimentally proved. In this issue, the main patterns of sediment properties' changes during the microwave irradiation process have been established and the equations, that describe the effect of capacity and duration of electromagnetic treatment on compression degree, humidity and ash content, have been obtained.

The comparison of the sewage sludge compaction degree has been carried out for various methods of their preliminary treatment: 1) with the flocculants Zetag (dose is 3,5 g per kg), 2) with the lime-reagent (dose is $2 \mathrm{~g} / \mathrm{kg}$ ), 3) pretreating with the SHF irradiation 10 minutes; 4) preheating by convectional way 30 minutes; 5) without any treatment. Experience results are shown on Figure 4.

The comparison of different variants of the sediment treatment discovered that the compression effectiveness of the SHF-processed sediment on the "Flow EM-1" plant is 7.6\% 
higher in comparison with sediments, processed with flocculants. The SHF way is $25 \%$ better, than the treatment with burnt lime and is $5.4 \%$ better then after the electric preheating. Optimum time of compression after the electromagnetic treatment is two hours that is 1.5 times lower, than it is necessary for compression of the unprocessed sediment.

\section{Discussion}

The preliminary technical and economic comparison of electricity and resource costs with using of enlarged indicators has been done. The tentative comparison of sediment treatment costs is presented in the Table 5 .

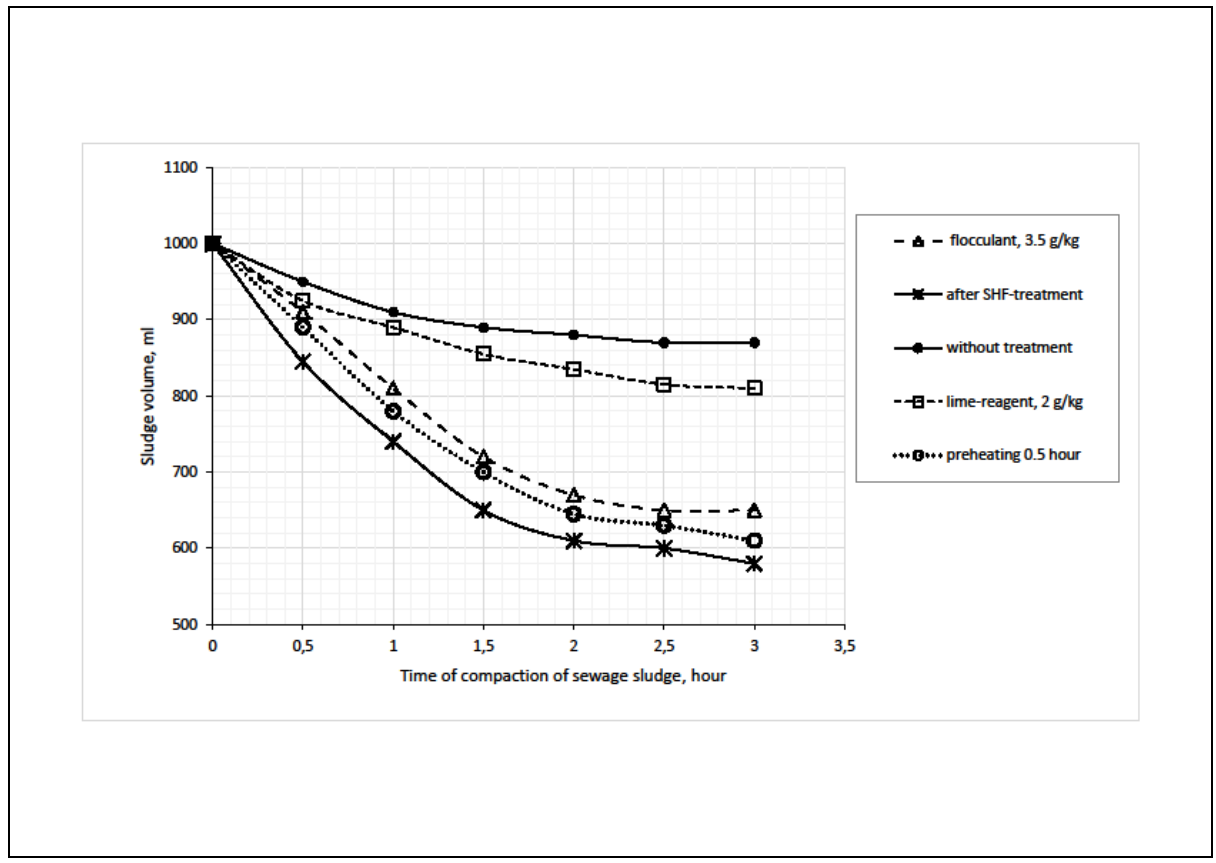

Fig. 4. The comparison of compaction degree.

Table 5. The comparison of costs of sludge treatment kinds.

\begin{tabular}{|c|c|c|c|}
\hline \multirow{2}{*}{$\begin{array}{c}\text { WWPT } \\
\text { Productivity, } \\
\mathrm{m}^{3} / \text { day }\end{array}$} & \multicolumn{2}{|c|}{ The cost of sewage sediments' treatment, euro/year } \\
\cline { 2 - 4 } & with SHF irradiation & with flocculants Zetag & $\begin{array}{c}\text { with electro- } \\
\text { preheating }\end{array}$ \\
\hline 5 & 13.5 & 23.9 & 37.8 \\
\hline 20 & 26.6 & 30.8 & 63.8 \\
\hline 200 & 210.3 & 285.0 & 478.5 \\
\hline 1000 & 906.2 & 1094.9 & 1359.6 \\
\hline
\end{tabular}

The fact that a prevented environmental damage is 2.72 thousand euro has been confirmed by calculations. The sludge treatment cost price in average is 1.2 times less than the existing scheme of the sediment treatment with the flocculants and is 1.5 times less than the traditional preheating. The introduction of the microwave method for the sludge treatment allows to decrease the sewage sediments' treatment and utilization cost by 1.3 times. The 
offered method of sewage sediments' treatment can be considered a variant of the expensive reagents' import substitution.

\section{Conclusion}

The research has shown that there are some advantages of the super high frequency irradiation in the municipal liquid waste treatment. Under the SHF process, the wastewater quality and sludge properties have changed for the better. After the microwave treatment, the organic matters in the wastewater decrease very fast. The efficiency of water treatment is able to reach from 25 to $85 \%$.

The heating rate of the precipitation during the microwave treatment is higher than the convection electrothermal heating. In the process of studying the question, it has been found out that the sediment compaction efficiency after the electromagnetic treatment is higher by $13-15 \%$ than after the traditional preheating. The SHF power consumption is lower in 2.02.5 times than the energy preheating.

The use of the microwave treatment at WWTP stations with a low or medium productivity is more advantageous than the use of the reagents.

The technical and economic comparison of the reagent method, the convection preheating and microwave irradiation have shown the advantages of the SHF using. The energy efficiency and the cost-effective use of electromagnetic SHF method for the liquid municipal waste treatment have been confirmed.

\section{References}

1. V. Kichigin, E. Palagin, Obrabotka i utilizatsiya osadkov prirodnykh i stochnykh vod: ucheb. Posobie (SGASU, Samara, 2008)

2. E. Vialkova, M. Zemlyanova, A. Pesheva, Ecology \& Safety 10, 121 (2016)

3. M. Zemlyanova, E. Vialkova, Trudy II Vserossiyskoy nauchnoy konferentsii s mezhdunarodnym uchastijem "Vodnyye i ekologicheskiye problemy Sibiri Tsentral'noy Azii" (Barnaul, 2014)

4. S. Dovgan', Ekologiya i promyishlennost Rossii 5, 28 (2012)

5. V. Tyagi, S. Lo, Renewable and Sustainable Energy Reviews 18, 288 (2013)

6. T. Komarova, Ecologicheskiye sistemy i pribory, 48 (2013)

7. L. Nikiforova, Intensifikatsiya raboty aerotenka s ispol'zovaniyem izbytochnoy energii potoka vozvratnogo aktivnogo ila: Avtoreferat dissertatsii na soiskaniye uchenoy stepeni kandidata tekhnicheskikh nauk (Pensa, 2002)

8. R. Minnigalimov, Razrabotka technologii pererabotky neftyanykh shlamov $s$ primeneniyem energii VCh i SVCh electromagnitnykh poley: Avtoreferat dissertatsii na soiskaniye uchenoy stepeni kandidata tekhnicheskikh nauk (Ufa, 2010)

9. S. Zhuravlev, S. Petrenko, I. Warm, Sposob obezzarazhivaniya promyshlennykh stochnykh vod, Patent RU 2123477 C1 (1996)

10. R. Uma Rani, Waste Management 33, 1119 (2013)

11. I. Gaponenkov, O. Fedorova, Vestnik MGTU 16, 681 (2013)

12. V. Kapustin, A. Korzhavy, Sostoyaniye i okhrana okruzhayuchey sredy v Kaluge. Informatsionny obzor, 42 (2009) 
13. V. Senkus, B. Stefanyuk, V. Senkus, S. Chasovnikov, I. Gridasov, A. Bogatyrev, N. Konakova, A. Kisel, Compleksnyy sposob bezreagentnoy ochistky stochnykh vod i briketirovaniya ila, Patent RU 2431510 C2, MPK CO2F 9/12 (2011)

14. A. Laptev, I. Abdullin, R. Akhiyarov, D. Bugay, O. Latypov, Sposob antibacterial'noy obrabotki potoka zhidkoy sredy, Patent RU 2376247 C2, MPK CO2F1 / 48 (2006)

15. S. Gunich, E. Yanchukovskaya, N. Dneprovskaya, Proceedings of Universities. Applied Chemistry and Biotechnology 7, 183 (2017)

16. S. Mehdizadeh, C. Eskicioglu, J. Bobowski, T. Johnson, Water research 47, 5040 (2013)

17. L. Obukhov, E. Vialkova, M. Zemlianova, Bezreagentnyy sposob obrabotki i obezvrezhivaniya osadkov stochnych vod Patent RU 2569533 C1, MPK CO2F 11/00, CO2F1/30, (2015)

18. T. Zou, H. Li, N. Zhao, C. Shi, Journal of Alloys and Compounds 1, 22 (2010)

19. G. Sapunov, Mikrovolnovyie pechi (2007) http://www.elremont.ru/svch/bt_rem19.php.

20. M. Watanabe, X. Qi, T. Aida, R. Lee Smith, The Development and Application of Microwave Heating (2012) 